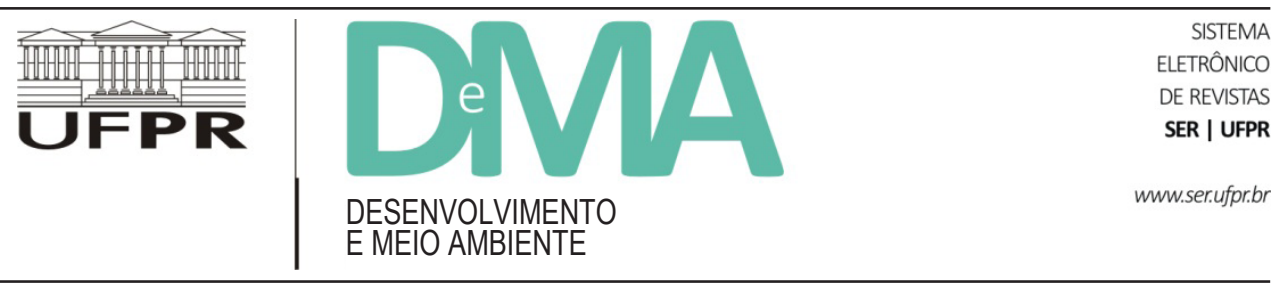

\title{
No mutirão da vida: pensando como um historiador ambiental
}

\section{In the Joint Effort of Life: Thinking as an Environmental Historian}

\author{
Diogo de Carvalho CABRAL ${ }^{1 *}$ \\ ${ }^{1}$ Programa de Pós-Graduação em População, Território e Estatísticas Públicas - Escola Nacional de Ciências Estatísticas - IBGE, Rio de \\ Janeiro, RJ, Brasil. \\ *E-mail de contato: diogo.cabral@ibge.gov.br
}

Ensaio recebido em 5 de setembro de 2013, versão final aceita em 16 de junho de 2014.

\begin{abstract}
RESUMO O ensaio defende a relevância da história ambiental como crítica dos esquemas de pensamento e atitude atualmente dominantes em relação ao mundo extra-humano. Argumenta-se que a civilização ocidental, sob a influência religiosa e filosófica do judaísmo-cristianismo, construiu sua identidade cultural em torno da ideia de criação, sobretudo a partir do Renascimento europeu. Transposto do domínio divino para o sublunar, esse "criacionismo" retrata o mundo como produto unilateral da ação humana - pois é a única criatura, no reino animal, orientada por uma razão autoconsciente. Os historiadores ambientais, por outro lado, partem de uma concepção descentralizada de agência para defender o princípio de que os humanos mais participam do que de fato criam; a criatividade reside nos encontros e relações que estabelecem, e não nos humanos em si mesmos. Em outras palavras, historiadores ambientais partem de um continuum humanidade-natureza e se perguntam pelas condições, fatores e processos responsáveis pela emergência de sistemas de pensamento calcados na "alterização" dos não humanos. Para ilustrar esse ponto, examina-se brevemente o processo histórico de substituição das populações ameríndias, nativas da Mata Atlântica, por populações mestiças neobrasileiras, a partir de 1500.
\end{abstract}

Palavras-chave: história ambiental; teoria ambiental; criatividade histórica.

ABSTRACT The essay argues for the importance of environmental history as a critique of the currently dominant ways of thinking and acting towards the extra-human world. It is argued that, under the religious and philosophical influence of Judeo-Christianism, Western civilization has built their cultural identity around the idea of creation, especially from the European Renaissance onwards. Transposed from the divine to the sublunary realm, this "creationism" portrays the world as a unilateral product of human action - since it is the only creature in the animal kingdom driven by a conscious reason. Environmental historians, on the other hand, start out from a decentralized conception of agency to defend the principle that humans participate rather than create; the creativity lies in the encounters and relationships they establish and not in humans themselves. In other words, environmental historians assume a humanity-nature continuum and ask themselves what conditions, factors and processes are responsible for the emergence of systems of thought rooted in the "othering" of non-humans. To 
illustrate this point, it is briefly examined the historical process of replacing the indigenous population, native to the Brazilian Atlantic Forest, by hybrid neo-European populations from 1500 onwards.

Keywords: environmental history; environmental theory; historical creativity.

\section{"[...] a vida é mutirão de todos, por todos remexida e} temperada"

João Guimarães Rosa (2001, p. 477)

\section{Introdução}

O objetivo deste ensaio é desenvolver um argumento de relevância para a disciplina - ou abordagem, como talvez prefiram alguns - da história ambiental. É verdade que ela talvez não precise de minha ajuda. Pode ser que sua importância seja evidente para muitos colegas que trabalham em outras disciplinas "ambientais". Mas pode ser também que eles não entendam essa relevância da mesma maneira que o autor dessas linhas. Diferentemente de uma certa concepção utilitarista, não considero que essa relevância se fundamente em qualquer serviço "prático" ou imediato possivelmente prestado a governantes, gestores e outros tomadores de decisão. Embora nada impeça ou mesmo desaconselhe uma atuação mais pragmática dos historiadores ambientais - participando das equipes de avaliação de impacto ambiental, tomando parte na formulação de políticas públicas, etc. -, estimo que esta não seja sua maior contribuição. ${ }^{1}$

Ela reside, a meu ver, no campo muito mais lento e difuso da mudança de mentalidade coletiva. As estruturas que sustentam o status quo não são apenas materiais, mas também "virtuais"; elas estão tanto na nossa mente quando na paisagem. Uma igreja, por exemplo, só pode continuar sendo uma igreja se clérigos, fiéis, visitantes e outros agentes continuarem tratando aquele edifício como uma igreja: indo às missas, ajoelhando-se diante do altar, gesticulando o sinal da cruz, etc. Da mesma forma, um campo petrolífero só é mantido enquanto tal à medida que as pessoas renovam sua "existência" produzindo e consumindo gasolina, plástico e outros derivados. As estruturas do mundo precisam ser "atualizadas", sancionadas e reproduzidas por nossos atos cotidianos - e por isso elas estão constantemente em risco (Sewell, 1992). Assim, uma estratégia que considero não apenas válida, mas fundamental para mudar o nosso atual modo de relacionamento com o mundo natural, é ampliar o leque de esquemas de pensamento e conduta disponível aos nossos concidadãos - inclusive os cientistas. Nesse aspecto, como espero mostrar nas próximas páginas, os historiadores ambientais têm muito a oferecer.

\section{Uma história promíscua}

Assim como "ecologia" antes dela, a expressão "história ambiental" extravasou os limites da academia e qualquer tentativa de domá-la é um mero exercício de futilidade. Mesmo no âmbito estreito da academia, não faz sentido monitorar e supervisionar a "correta" aplicação do rótulo. Quem poderá dizer que aquilo que o geólogo ou o geógrafo interessado na erosão quaternária fazem não é história ambiental? Qualquer estudo que enfoque o mundo biofísico em mudança pode reivindicar esse rótulo.

Não obstante, há um sentido mais estrito e historicamente comprometido do termo. Como sabemos, uma história ambiental entendida como disciplina historiográfica emergiu nos anos 1970, nos Estados Unidos da América. Os detalhes intelectuais e ideológicos dessa emergência já foram abordados de forma competente por Richard White (1985), Alfred Crosby (1995) e, mais recentemente, José Augusto Pádua (2010), entre outros, e não precisam ser retomados aqui. O que importa ressaltar, para efeito de nossa discussão, é que as definições do campo atualmente encontradas na literatura ainda giram em torno do que se disse naquela primeira década da história ambiental. A formulação seminal é do historiador Roderick Nash que, em 1972, falou no "contato passado do homem com seu habitat total".

${ }^{1}$ Sobre a utilidade dos conhecimentos gerados pelos historiadores ambientais para a formulação e avaliação de políticas públicas, ver Dovers (2000). 
Herdeiro direto da tradição da historiografia intelectual e das mentalidades, Nash não parecia muito inclinado a aceitar as implicações materialistas de sua formulação. Ele não pretendia encampar uma "história da terra à maneira dos geólogos". Mesmo admitindo que o historiador ambiental deveria descrever as mudanças na terra, alertou que seu interesse primordial estava nas atitudes humanas imbricadas nessa mudança - nos "valores, ideais, ambições e medos do homem". O ambiente não seria acessado diretamente como materialidade, mas, antes, como um "documento histórico". Posto que o ambiente fosse "sintético" - ou seja, criado pelos humanos -, sua leitura poderia desvelar a cultura humana que o havia produzido, exatamente como a leitura de um romance, de um jornal ou de uma oração patriótica. De fato, os primeiros trabalhos de história ambiental - clássicos como Wilderness and the American Mind, do próprio Nash, e Traces on the Rhodian Shore, de Clarence Glacken, ambos publicados em 1967 - não abordaram os efeitos das mudanças físico-ambientais sobre as sociedades humanas, mas sim o pensamento e o discurso de pessoas e instituições a respeito daquilo que eles imaginavam ser a "natureza".

Nesse tipo de abordagem, conforme colocou White (1985, p. 316), a natureza torna-se "uma sala de espelhos onde nós vemos não ela, mas sim reflexos dinâmicos de nosso próprio progresso cultural". Caso tivesse mantido ferrenhamente essa orientação, a história ambiental provavelmente teria murchado e se retraído de volta aos seus campos "parentais", a história intelectual e a história política. Todavia, no mesmo ano da publicação do citado ensaio de Nash, Alfred Crosby (2003[1972]) lançava seu magistral The Columbian Exchange, um incisivo relato histórico sobre a biologia do encontro colonial americano. Quatro anos depois, foi a vez de William McNeill (1976) publicar Plagues and Peoples, um abrangente estudo epidemiológico e demográfico sobre o papel das doenças na história humana, desde as origens africanas da espécie. Estas duas obras provavelmente exerceram uma poderosa influência sobre a disciplina que nascia, ao mostrar que o conhecimento biológico podia ser mobilizado para contar histórias sobre povoamento, encontros culturais e outros temas tradicionalmente abordados pelos historiadores.
Qualquer que tenha sido essa influência, contudo, o fato é que, no final dos anos 1970 e durante toda a década seguinte, uma versão solidamente materialista da história ambiental surgiu da pena de autores como Donald Worster, Richard White, Stephen Pyne, Warren Dean, William Cronon e o próprio Crosby. Todos eles, de uma forma ou de outra - em formulações teóricas ou na prática historiográfica -, procuravam trazer a materialidade não humana para dentro da história. Para Worster (1988), particularmente, a história ambiental seria uma "nova história", uma abordagem todo-inclusiva que, de certa forma, completaria o processo de transição de uma história política restrita às guerras e intrigas palacianas para uma história que mergulha na experiência das pessoas comuns e, então, na própria terra.

Acredito ser justo afirmar que a história ambiental é, basicamente, um estudo sobre promiscuidade. Trata-se de reconduzir conceitualmente os humanos e suas atividades a um mundo vivido concretamente, onde eles enfiam seus pés na lama, sujam-se de fuligem, excretam rejeitos, matam animais para comer (e às vezes são mortos por eles) - enfim, onde eles sentem, na pele, o peso do mundo. Historiadores ambientais rastreiam a sujeira (dirt), nas vidas humanas (Stroud, 2003). Desse modo, histórias de conceitos, mentalidades e conflitos sobre recursos, por exemplo, são histórias ambientais apenas na medida em que os recursos e a terra, eles mesmos, são afetados e mudam o sistema da vida ao redor deles (McNeill, 2010). Mesmo a ênfase recente nos discursos e nas histórias como modeladoras da natureza - uma tendência que, para Richard White (2004), constitui uma "virada cultural" - não aliena a disciplina do mundo material não humano. Esse mundo nunca irá se diluir totalmente em cultura humana, assim como o entendimento cultural acerca dele nunca será uma reprodução perfeita, mas apenas uma construção parcial. Ainda assim, esses dois planos da realidade são inseparáveis. Por mais que os desejos e necessidades humanos tenham alguma autonomia e, em certo sentido, "construam" seus próprios objetos, eles precisam dialogar com a terra, que é o laboratório onde desejos e necessidades podem ser efetivamente aplacados, reproduzidos e transformados (Marx, 1991).

No entanto, um dos mais poderosos motores da história humana consiste no fato de que os humanos 
nunca tiveram, não têm e nunca terão completo controle sobre a biosfera. Nas palavras de White (1985, p. 335), humanos "podem pensar o que eles querem; eles não podem sempre fazer o que eles querem, e nem tudo o que eles fazem sai como planejado" (ênfases no original). Resultados inesperados acontecem porque, ao contrário do que sustenta uma forte tradição das ciências sociais - o chamado "paradigma do isencionalismo" (Catton \& Dunlap, 1978) -, os humanos vivem no meio de outras espécies de organismos e de outras coisas. Mais do que isso: eles se fazem "humanos" e constroem uma sociedade especificamente "humana" apenas na medida em que convivem e se misturam com o que não é humano (Abram, 1997). Em outras palavras, imprevisibilidade é o preço de nossa humanidade.

Humanos são seres naturais que, necessariamente, dialogam com outros seres naturais na construção de sua existência histórica. É por isso que os historiadores ambientais alargaram muito o elenco de dramatis personae da historiografia tradicional. Ao lado de reis, rainhas, presidentes, ministros, parlamentares, colonos, agricultores, operários, comerciantes, soldados, etc., eles colocam águas, solos, movimentos tectônicos, bichos, plantas, transferência de energia, seleção natural, etc., como agentes ativos na construção da realidade histórica. "Devolvendo à terra e ao clima o tipo de criatividade imprevisível convencionalmente reservada aos atores humanos", afirmou Simon Schama (1995, p. 13), "esses escritores criaram histórias nas quais o homem não é o ser último e a finalidade última da história".

Embora eu concorde, no geral, com Schama, acredito que haja uma maneira ainda mais precisa e contundente de enunciar a ruptura teórica operada pelos historiadores ambientais. Trata-se de dizer que eles questionam o conceito segundo o qual a história é feita apenas pelos humanos ou, ainda mais enfaticamente, de que há qualquer coisa como "criações humanas". Minha objeção - e aqui eu suponho que falo por muitos outros colegas historiadores ambientais - não é contra a noção mais ou menos neutra de criação enquanto "surgimento/ produção do novo", pois é difícil pensar-se em qualquer discurso histórico que não apele a ela, de uma forma ou de outra. A objeção, na verdade, direciona-se contra a intencionalidade metafísica a que a ideia de criação foi vinculada, na tradição religiosa e filosófica que deu forma ao Ocidente moderno: o judaísmo-cristianismo. Desde o clássico artigo de Lynn White (1967), tornou-se lugar-comum afirmar que a mentalidade judaico-cristã foi um poderoso fator de alteração ecológica do planeta. "Frutificai e multiplicai-vos, enchei a terra e submetei-a" (Gênesis, 1, 28): essas são as ordens de Deus aos humanos, segundo a Bíblia hebraica. No entanto, embora White e os estudiosos posteriores tenham ressaltado, corretamente, esse aspecto hierarquizante da doutrina judaico-cristã - quer dizer, o preceito de que os humanos foram feitos para reinarem sobre o restante da criação -, a ideia de criação ela mesma não foi devidamente avaliada.

\section{O “criacionismo" moderno}

No livro do Gênesis, aprendemos que, para poderem exercer o domínio sobre a biosfera, homem e mulher foram criados "à imagem e semelhança" de Deus. Os humanos refletem Deus nesse mundo criado. Da mesma forma que seu criador, embora em contato com a natureza - e "revelados" por suas obras materiais -, eles não fazem parte dela como os bichos e as plantas e as rochas. Humanos são como "administradores" ou "gerentes" a serviço de Deus e se, por um lado, eles não deixam de ser criaturas, por outro também participam da divindade a partir do qual é delegada sua "gerência". Nos Salmos $(8: 5,6)$, lemos: "Pois pouco menor o fizeste [o homem] do que Deus [...]. Fizeste com que ele tenha domínio sobre as obras das tuas mãos; tudo puseste debaixo de seus pés". E em outro lugar (Salmos 115:16): "Os céus são os céus do Senhor; mas a terra a deu aos filhos dos homens".

De acordo com a Bíblia, os humanos foram criados de forma a desfrutar a felicidade e a vida eterna, e, portanto, possuem necessariamente as faculdades mentais para conhecer a criação e abraçar a fé (Glacken, 1967, p. 166, 168, 359-360). Desde o começo, eles foram assistidos pela Sabedoria, entidade criada por Deus antes mesmo da criação do mundo; ela, na verdade, foi o "mestre de obras" de Deus nesse empreendimento. No afresco "A criação de Adão", de Michelangelo, podemos observá-la do lado esquerdo de Deus; ela olhou pelo primeiro homem, instruiu-o e lhe deu domínio sobre as outras criaturas (Rzepinska, 1994). No Livro da Sabedo- 
ria, lemos que "o pai do mundo [Adão], que foi criado sozinho, foi ela [a Sabedoria] que cuidou dele; tirou-o de seu próprio pecado e lhe deu o poder de reinar sobre todas as coisas".

É claro que o pecado original resultara da vontade de Eva de conhecer o bem e o mal, elevando-se à condição do criador. Desde essa desgraça, os humanos haviam sido obrigados a ganhar seu sustento por meio do trabalho. Muitos teólogos medievais acreditavam que a Terra vinha envelhecendo e perdendo sua vitalidade. Ainda assim, conforme apontou o geógrafo Clarence Glacken, é difícil exagerar a importância histórica dessa ideia de que

o homem, por mais pecador que seja, ocupa uma posição na terra comparável àquela de Deus no universo, como uma possessão individual, um domínio de administração, tem sido uma das ideias-chave no pensamento religioso e filosófico da civilização ocidental no que concerne ao lugar do homem na natureza (Glacken, 1967, p. 155).

No entanto, é preciso salientar que, embora as sagradas escrituras ensinem que os humanos foram criados "à imagem e semelhança" do criador, a noção de criatividade propriamente humana, durante grande parte da história do "cristianismo doutrinário", foi interditada aos fiéis. Ela parecia violar a transcendência de Deus. Sua herética sugestão constituiria uma repetição da desastrosa tentação de "ser como Deus" que havia levado Eva e Adão ao pecado e à expulsão do paraíso. Além disso, em detrimento do Livro do Gênesis, a cultura escolástica medieval preferia a teoria grega clássica de que Deus dera forma ao mundo imprimindo suas ideias sobre uma matéria primordial desde sempre existente. Nesse mito, o "demiurgo", como o chamou Platão, não era propriamente o criador do mundo, mas seu mero construtor. De maneira análoga, a atividade humana não era considerada capaz de criar, em nenhum sentido absoluto; ela se baseava na descoberta e na reprodução da obra do demiurgo - ela mesma apenas uma "modelagem" usando materiais preexistentes (Glacken, 1967; Bouwsma, 1993).

Uma noção clara de criatividade humana emergiria somente na época do Renascimento europeu, a partir do final do século XV. É verdade que, a princípio, não houve uma ruptura com o pensamento anterior e a criatividade continuou associada à capacidade de imitar o "artesanato" divino. Muitas vezes, essa imitação era considerada como inerentemente imperfeita. A natureza era sempre melhor do que a "arte" (no antigo sentido de algo "instituído" e, portanto, oposto à natureza). Mas esse conceito continha tensões internas, como a impossibilidade lógica de se imitar perfeitamente algo (o original imitado não é uma imitação). Na luta para superar essas tensões, a ênfase, na descrição e na explicação do processo criativo, foi se deslocando da obra divina para o gênio do "artista"; cada vez mais era ressaltada sua capacidade de imitar não as coisas particulares, mas as formas ou princípios universais que as haviam produzido.

Contribuíram para esse deslocamento as inúmeras turbulências do século XVI: pestes, guerras religiosas e o encolhimento da cristandade sob a pressão dos turcos otomanos, cisma da igreja católica, etc. Menos confiantes no poder da razão humana e de suas filosofias - dentre elas o modelo criacionista clássico -, os humanistas progressivamente se convenciam de que verdades confiáveis sobre a condição e o destino da humanidade podiam ser descobertas apenas na Bíblia. Além disso, o interesse dos renascentistas pela antiguidade estimulou o desenvolvimento de instrumentos filológicos que, aplicados às sagradas escrituras, tornaram seus textos cada vez mais acessíveis. Tudo isso conduziu à exumação da história bíblica do Gênesis, com profundas consequências para a concepção de criatividade (Bouwsma, 1993).

O reconhecimento da criatividade radical de Deus sancionava a criatividade de suas criaturas humanas. Embora continuassem aceitando o dogma de que o criador último de todas as coisas fosse Deus, os pensadores renascentistas - estimulados pela observação da expansão geográfica das atividades econômicas e de seu poder de alteração ecológica - ressaltavam que os humanos, embora trabalhassem com materiais encontrados prontos, transformavam-nos e recombinavam-nos de modo a sintetizar novos objetos e recursos. "A providência universal pertence a Deus, que é a causa universal”, afirmara, ainda no final do século XV, o humanista florentino Marsílio Ficino: "Por isso o homem, que provê geralmente para todas as coisas, tanto animadas quanto inanimadas, é um tipo de deus" (Ficino, 1944 apud Glacken, 1967, p. 463, ênfase minha). 
Era como se, no plano terreno, a transformação de substâncias e de outras espécies - o tema da domesticação é recorrente - desempenhasse papel análogo ao da criação "propriamente dita", no plano divino. Nos Diálogos das grandezas do Brasil - escritos, no começo do século XVII, provavelmente por Ambrósio Fernandes Brandão, um cristão-novo, senhor de engenho e escrivão do açúcar da Paraíba -, uma fala do personagem Alviano retrata bem essa concepção:

[...] sei muito bem que as coisas todas foram produzidas de um princípio, o qual foi a primeira criação que nelas fez Deus; e posto que vemos alguns frutos, que parecem não ser criados neste princípio, como são as limas doces, laranjas e outras semelhantes, que a indústria humana se fez produzir por via de enxertos e outros modos que para isso buscaram todavia a causa de onde procedem são daquelas que por Deus foram primeiramente criadas (Anônimo, 1977, p. 27).

A princípio uma inovação chocante demais para ser amplamente aceita, a ideia da criatividade humana embasou, nos séculos que se seguiram ao Renascimento, uma possibilidade perene de autocompreensão e autoestimulação por parte dos europeus - contribuindo decisivamente para a modelagem da cultura moderna (Bouwsma, 1993). De um modo geral, pode-se dizer que o pensamento dos séculos XVII e XVIII deu continuidade a essa escalada de confiança na noção de que a acumulação de conhecimento científico e expertise técnico estivesse aumentando o poder dos humanos sobre o restante da natureza. A despeito de algumas correntes dissidentes - como aqueles que ainda viam na antiguidade clássica o apogeu da realização humana ou aqueles que acreditavam que o pecado original desencadeara um irreversível processo de degradação do planeta -, a tendência predominante era o franco otimismo em relação à possibilidade de manipulação e transformação dos ambientes terrenos (Glacken, 1967, p. 471).

O estudioso da história do pensamento percebe que as teorias sobre o lugar e o papel da humanidade na na- tureza secularizam-se ao longo do setecentos (Glacken, 1967 , p. 620). No entanto, ainda que o argumento do projeto divino tenha sido quase totalmente expurgado das elucubrações científicas mais sérias, o forte antropocentrismo - alguns diriam antropoexclusivismo - que ele havia precipitado permaneceu como um traço básico da mentalidade ocidental. No final do século XVIII, mesmo os pensadores mais hostis à religião doutrinária aceitavam a ideia de que o destino da humanidade era progredir e se aperfeiçoar contínua e indefinidamente, superando quaisquer obstáculos terrenos. " "Em sua ênfase no melhoramento humano, o ambiente frequentemente parecia se tornar mais e mais abstrato", escreveu Glacken (1967, p. 637) acerca desse progressismo.

Ao longo da centúria seguinte, com a industrialização europeia e o início do que alguns pesquisadores vêm chamando de "Antropoceno" - uma nova época geológica caracterizada pela predominância da agência humana na dinâmica biosférica -, a ideia de que a criatividade humana é livre e ilimitada ganhou um momentum inédito. A experiência da mudança ecológica foi especialmente intensa para quem vivia na Inglaterra, país que inaugurou o uso sistemático e maciço de energia fóssil. $\mathrm{O}$ escritor e historiador inglês H. G. Wells, um homem que cresceu assistindo à maturação da "revolução mecânica", no último quartel do oitocentos, expressou de forma quase paradigmática esse sentimento triunfalista:

\begin{abstract}
Na casa ou no navio dos tempos antigos, a matéria determinava tudo - o material e suas necessidades tinham de ser obedecidos cegamente; nos novos tempos, a matéria havia sido capturada, transformada, coagida. Pensemos no carvão e no ferro e na areia extraídos de ribanceiras e das profundezas das minas, em todo o material arrancado, forjado, fundido e moldado para afinal ser arremessado, um delgado e brilhante pináculo de aço e vidro, duzentos metros acima da multidão da cidade! (Wells, 2011[1922], p. 302-303).
\end{abstract}

Celebrava-se uma suposta "libertação" da espécie. Aparentemente, os humanos já não se dobravam mais à

\footnotetext{
${ }^{2}$ Com exceção, evidentemente, do pároco Thomas Malthus e seu princípio de que o planeta impunha limites naturais ao crescimento populacional (ver Glacken, 1967, p. 637-649).
} 
natureza, mas a controlavam e transformavam segundo seus próprios interesses e caprichos. Essa ideologia progressista passou então a alimentar, de forma quase mítica, tanto o comportamento econômico quanto o pensamento social (gerando, inclusive, algumas poucas, mas célebres, reações críticas, como as de H. D. Thoreau e G. P. Marsh, por exemplo). No campo da historiografia e das ciências sociais, ela acabou desembocando no paradigma de que "a história da civilização é a estória [story] do homem desde uma época em que a natureza o controlava até [outra época em que] ele controlava a natureza" - uma reversão atribuída ao "aumento do conhecimento, da perícia técnica e da engenhosidade" (Glacken, 1967, p. 96). Bebendo no racionalismo do "Século das Luzes", o progressismo econômico do oitocentos reforçou a noção judaico-cristã de que há uma diferença essencial entre animais humanos e não humanos: a capacidade mental e cultural.

$\mathrm{Na}$ Geografia, que se estruturou como disciplina acadêmica exatamente durante o take-off da economia industrial europeia, esse tipo de aula é ministrado desde, pelo menos, Élisée Reclus. Em seu La Terre, de 1881, ele escreveu:

Sem dúvida, entre as obras que animais de ordem inferior realizaram sobre a Terra, as ilhotas construídas pelos corais ultrapassam, em extensão, os trabalhos do homem; mas essas construções prosseguem através dos séculos de maneira uniforme e nunca acrescentam um traço novo à fisionomia geral do globo: são sempre os mesmos recifes, as mesmas terras lentamente emersas, como bancos de aluviões fluviais ou marinhas, enquanto o trabalho do homem, continuamente modificado, dá à superfície terrestre a maior diversidade de aspectos e a renova, por assim dizer, a cada novo progresso da raça humana, em sabedoria e experiência (Reclus, 1985[1881], p. 41-42).

Essa distinção - herdada de pensadores tão antigos quanto os estoicos e reelaborada à luz do cientificismo oitocentista - é construída sobre a premissa de que os seres vivos não humanos são "meros organismos" e que, portanto, limitam-se a reagir, de forma passiva e geneticamente programada, aos estímulos ambientais. Falta-lhes "espírito" e, portanto, motivação e ação consciente/criativa (Ingold, 2002).
É essa assunção que está na base da opinião moderna sobre a domesticação vegetal e animal, por exemplo. É surpreendente notar como, mesmo atualmente, muitos estudiosos do tema ainda partem da premissa de que o "Homem não apenas domina os animais pela força, ele também os governa, mantém e ensina", como afirmou Ficino (1944 apud Glacken, 1967, p. 463), quase meio milênio atrás. No final do século XVIII, Buffon não deixou dúvidas quanto à mentalidade da (nossa?) época: a domesticação impunha aos animais não humanos o "jugo da escravidão". Para o naturalista francês, quase tudo dependia da força e da engenhosidade da cultura humana; sua explicação para o menor número de animais domesticados no Novo Mundo em relação ao Velho, por exemplo, era que os povos ameríndios eram mais fracos do que os eurasianos (embora ele também fosse da opinião de que a natureza americana era relativamente mais fraca) (Glacken, 1967, p. 674-675, 680-682).

Para a filósofa Val Plumwood (2006), trata-se de um esquema hegemônico de pensamento, próprio da tradição ocidental, e que identifica agência exclusivamente com pensamento racional, concedendo aos seres não humanos tão somente o papel de "meios" externos, passivos e maleáveis. Em nenhuma outra tendência tecnocientífica do mundo contemporâneo os efeitos desse esquema podem ser vistos mais claramente do que nos movimentos para patentear espécies de organismos e colocá-los, assim, sob a égide dos direitos de propriedade - criações da razão, supostamente. Empresas do ramo de genética agrícola "criam" riqueza como se fossem causas externas e inteligentes, negando a criatividade presente na própria organização do DNA, por exemplo. "Se nós enquadramos nossos conceitos em termos desse padrão de divisão senhor-escravo", escreveu Plumwood (2006, p. 119), "no devido tempo fabricamos um mundo escravista que serve para modelá-lo, confirmá-lo e exemplificá-lo, e ficamos incapazes de conceber qualquer coisa além disso".

\section{Participando da natureza}

Na crítica a essa visão de mundo, a primeira coisa que o historiador ambiental precisa fazer é ressaltar que a domesticação, pelo menos no início (cerca de 10 mil 
anos atrás), não foi um processo assim tão consciente quanto poderia parecer. A rigor, a domesticação - no sentido amplo de modificação genética resultante de relações mutualísticas - já era "praticada" muito antes do surgimento do Homo sapiens. Entendida como mudança genética resultante de relações mutualísticas, a domesticação tornou-se um processo extremamente comum no planeta, desde o surgimento da vida. Entre os morangos silvestres, por exemplo, frutas que amadureciam mais doces, bem como exibindo um vermelho mais vivo e suculento, tinham proporcionalmente mais chances de serem selecionadas pelos tordos e outras espécies de pássaros que, a partir de um certo momento, passaram a se alimentar delas. Ao aproveitar essa fonte de comida, as aves ajudavam na perpetuação e dispersão do morango - mas não sem modelá-lo enquanto espécie. Assim como os pássaros "domesticaram” os morangos, os esquilos "domesticaram" as bolotas dos carvalhos; os morcegos, as mangas; as formigas, algumas ciperáceas (Diamond, 2012).

A mesma coisa aconteceu com os humanos. Os primeiros estágios da domesticação vegetal consistiram em humanos coletando frutos e glandes silvestres e depois descartando as sementes por meio da defecação - as quais eram então "plantadas". Exatamente como no caso de outros animais, as latrinas tornaram-se "viveiros" acidentais. Era para lá que os coletores se dirigiam quando precisavam de mais alimento. Naturalmente, eles continuavam se servindo das frutas mais apetitosas; no longo prazo, o resultado foi a seleção pouco consciente das plantas mais interessantes aos humanos (Diamond, 2012).

Evidentemente, a certa altura, começaram a ser praticados a seleção e o manejo consciente. No entanto, mesmo depois que esse estágio foi alcançado - quando iniciada, em outras palavras, a fase propriamente agropecuária da história humana -, os esforços de domesticação nem sempre surtiram resultados satisfatórios. Embora necessárias, vontade e técnica não são suficientes. Jared Diamond (2012) mostrou como as espécies não humanas devem possuir certos atributos e disposições para se "candidatarem" à parceria com o Homo sapiens. Prioridade no acesso às sementes e velocidade de crescimento parecem ser os fatores mais importantes. O carvalho, por exemplo, não oferece essas facilidades. Embora há muito apreciadas pelos campônios tanto do Velho quando do Novo Mundo, as bolotas dos carvalhos, no entanto, sempre foram disputadas com os esquilos, que rápida e vorazmente escalam as árvores para as coletar, tão logo maduras. Eles armazenam muitas bolotas no solo e de vez em quando esquecem de buscar as que enterraram (é assim que germinam novos carvalhos). Assim, com bilhões de esquilos espalhando, cada um, centenas de bolotas por ano, em praticamente qualquer pedaço de solo disponível, sempre foi difícil para os humanos selecionar as árvores com as características desejadas.

Outro problema é o tempo que leva até uma bolota semeada se desenvolver e chegar à idade reprodutiva. Enquanto a safra do trigo acontece depois de alguns poucos meses da semeadura e as amendoeiras - uma comparação certamente mais justa - começam a produzir após três ou quatro anos de plantadas, os carvalhos podem permanecer improdutivos por uma década ou mais. Como se isso não bastasse, há uma dificuldade genética: nas bolotas, o característico gosto amargo é controlado por muitos genes, e não apenas por um, como no caso das amêndoas. Assim, se os domesticadores plantassem amêndoas ou bolotas a partir de uma árvore mutante não amarga, as leis da genética determinam que metade das amêndoas produzidas pelo novo indivíduo não seria amarga, mas, por outro lado, que quase todas as bolotas o seriam.

Além de ser condicionada por certos atributos das espécies silvestres, a domesticação, uma vez consumada, vincula as duas espécies parceiras de uma tal forma que se torna impossível falar no destino de cada uma, separadamente. Sabemos que a dependência de uma única espécie de planta deixa povos inteiros à mercê de fomes devastadoras, como na Irlanda, em 1845 - quando as lavouras de batata, o alimento básico do povo, foram atacadas por um oomiceto (algo como um fungo). Da mesma forma, quando as populações humanas perecem, as plantas e animais que elas haviam domesticado tendem a perecer junto, já que o processo de domesticação compromete severamente a adaptabilidade ecológica desses organismos. Considerando-se a biota ainda existente nos dias de hoje, é possível afirmar que, até o momento do contato com os europeus, os aborígenes da Amazônia haviam domesticado pelo menos 138 espécies vegetais, entre tubérculos, cereais, árvores frutíferas e 
outros tipos de plantas. É provável, contudo, como sugere Charles Clement, que essa lista seja muito maior - talvez uma ordem de magnitude maior. As altas densidades demográficas que hoje sabemos serem características da Amazônia pré-colombiana - em partes do vale do Solimões, por exemplo, a taxa era de 28 habitantes/ $\mathrm{km}^{2}$, segundo estimativas - estariam provavelmente associadas à lavoura intensiva e altamente diversificada. A maior parte desses cultígenos pode ter sido extinta no bojo da devastação da população ameríndia, pois as plantas já se encontravam completamente dependentes da manutenção humana e não conseguiam se reproduzir no ambiente selvagem (Clement, 1999).

Desse modo, podemos dizer que o processo envolve a domesticação tanto de uma população humana quanto a de uma população não humana (Russell, 2011). Essa característica da domesticação aponta para um processo coevolutivo amplo e intrincado. Ao selecionar certas plantas e animais, os humanos, em contrapartida, são selecionados pelas características específicas desses organismos. Desafiando antigas assunções de que a evolução opera somente numa escala temporal muito ampla (de milhões ou, pelo menos, dezenas de milhares de anos), alguns biólogos agora argumentam que muitos genes humanos foram selecionados recentemente e por pressões seletivas geradas pelas próprias práticas humanas. $^{3}$

O caso mais bem estudado dessa "coevolução genético-cultural" é o da tolerância à lactose. Para nós, brasileiros e americanos em geral, beber leite é uma coisa tão normal que raramente chegamos a suspeitar que a maior parte dos indivíduos adultos da espécie humana não pode fazer isso. O mais comum é que a capacidade de digerir lactose desapareça na infância. Em algumas populações, contudo, ela persiste até a vida adulta. Esse traço é comum em europeus do norte e do oeste - bem como em seus descendentes americanos - e em sociedades pastoris da África e do Oriente Médio, mas quase completamente ausente em outros lugares. As pesquisas mostram que os primeiros europeus neolíticos não possuíam o gene que controla a tolerância à lactose e que a seleção desse gene ocorreu entre cinco e dez mil anos atrás - ou seja, apenas a partir do desenvolvimento de uma economia leiteira. A capacidade de digerir leite provavelmente conferiu uma vantagem seletiva, pois fornecia um suprimento adicional de proteína, calorias e cálcio, especialmente após colheitas magras (Laland et al., 2010). Assim, ao domesticar o boi, a cabra e outros animais, e estimular a produção leiteira - bem como, evidentemente, seu consumo - os humanos foram eles mesmos "domesticados".

Entretanto, o aspecto mais importante desse processo coevolucionário, pelo menos nos últimos dez mil anos, não foi a mudança genética. Porquanto a cultura muda muito mais rapidamente do que os genes, a coevolução de humanos e outras espécies envolve transformação cultural mais frequentemente do que transformação genética. Ao longo da história, plantas e animais domesticados não favoreceram apenas certos espécimes de Homo sapiens em detrimento de outros, mas, principalmente, certas instituições e formas de organização econômica e social em detrimento de outras. Há inúmeros exemplos que poderiam ser mobilizados, mas nos detenhamos no mais poderoso deles: a Revolução Industrial, talvez o maior símbolo do engenho e do domínio humanos no imaginário histórico comum. Estudando a indústria do algodão, o historiador Edmund Russell (2011) avança a hipótese de que a mecanização da produção têxtil, na Inglaterra setecentista, foi "viabilizada" pela evolução biológica das espécies de algodão e pelas possibilidades que ela abriu aos cultivadores.

De fato, o algodão é um caso único na história da agricultura. Em busca de tricomas unicelulares, ou fibras, os humanos domesticaram, de modo independente, nada menos do que quatro espécies distintas; duas delas são nativas do Velho Mundo (Gossypium arboreum e G. herbaceum) e duas do Novo Mundo (G. hirsutum e G. narbadense). As espécies americanas constituem aquilo que os geneticistas chamam de alopoliploides, ou seja, híbridos cujos genomas contêm dois conjuntos completos de cromossomos, cada um derivado de uma das duas espécies parentais. O interessante é que essa

\footnotetext{
${ }^{3}$ Aqui é preciso lembrar que evolução genética não é sinônimo de especiação (i.e., surgimento de novas espécies). Qualquer mudança genética caracteriza evolução. Há evolução mesmo que apenas um gene torne-se mais ou menos comum em uma população, ao longo das gerações. Ver Russell (2011, p. 12).
} 
hibridização reuniu as duas linhagens derivadas da mais antiga clivagem no gênero Gossypium: a linhagem nativa da América e a linhagem nativa da África, que haviam estado separadas por dezenas de milhões de anos.

No contexto de nossa discussão, contudo, o mais importante é que essa hibridização duplicadora de genes propiciou maior variabilidade de traços morfológicos, fisiológicos e de desenvolvimento, uma oportunidade aproveitada pelos domesticadores ameríndios em sua busca por fibras mais longas. Neste aspecto, as espécies domesticadas nas Américas levam a palma sobre aquelas domesticadas na África e Ásia (Wendel \& Cronn, 2003). Fibras mais longas proporcionam fios mais fortes, mais preparados para aguentar os rigores do processamento maquinal. Tão logo o algodão americano começou a ser importado pela Grã-Bretanha, no começo do século XVIII, inventores puderam desenvolver máquinas para executar essas tarefas - abandonando a delicadeza outrora necessária ao tratamento manual dos tecelões. Essa interpretação desafia a visão tradicional de que a industrialização, de alguma forma, libertou a humanidade das dinâmicas naturais. A evolução biológica do algodão pode ter sido tão importante quanto o engenho de inventores ingleses na mecanização da indústria têxtil.

Espero que, a essa altura, tenha ficado claro que os historiadores ambientais não pretendem reabilitar as teorias do determinismo climático/geográfico do final do século XIX e começo do XX. Não se trata disso, absolutamente, mas sim de acentuar a relação dialética entre os agentes culturais humanos e o restante da biosfera. Nós humanos somos apenas uma dentre inúmeras espécies convivendo em imensas e complexas comunidades bióticas. Isto sem falar nos elementos abióticos que estão em constante trânsito nessas comunidades. Nossa vida e nosso ser são moldados por essa convivência. Assim, evocar a extra-humanidade não significa cair na armadilha de um "fetichismo da natureza", atribuindolhe papel determinante no caminhar da vida social. A ecologia que caracteriza a abordagem histórico-ambiental não se manifesta somente como incorporação de novas variáveis, mas também como um método de pesquisa e construção narrativa que assume uma inter-relação não determinística entre as todas as variáveis consideradas.

Essa postura metodológica visa recuperar um mundo histórico mais integral. Por isso, um argumento implícito na maior parte da historiografia ambiental é o de que "ambientes" não são quadros de referência, mas configurações dinâmicas. Já não se trata, como faziam os geógrafos do passado, de fazer suceder ao exame do meio biofísico a história do povoamento humano. Ambientes não guardam uma relação de precedência com os seres vivos que eles "abrigam". Na medida em que um "ambiente" só pode ser reconhecido em relação àquilo que ele envolve - desde que, em outras palavras, é a silhueta que constitui o fundo -, o processo de formação de um organismo, de uma espécie, de uma população, de uma comunidade, é também o processo de formação de seu ambiente (Ingold, 1990). ${ }^{4}$

Além disso, como o "ambiente" de um organismo inclui outros organismos, é forçoso concluir que a distinção metafórica entre cenário/palco e personagem/ator - tantas vezes utilizada para caracterizar as relações entre geografia e história - é completamente inadequada. Ela deve ser substituída por uma imagem intrigante: uma peça de teatro em que, como parte integrante do drama, os atores constroem o cenário de atuação usando seus próprios corpos ou, no máximo, próteses que ampliassem seu alcance. $\mathrm{O}$ poder metafórico desta imagem consiste em nos mostrar que, desde o começo, o que se apresenta é um "campo generativo contínuo" em que cada elemento atua como o ambiente dos demais, criando a si mesmo e aos outros. Um agricultor humano é tão "ambiental" em relação às plantas das quais cuida quanto estas são em relação a ele. Em suma, os historiadores ambientais entendem que as relações entre humanos e "natureza" são internas; eles procuram substituir o modelo de criação pelo modelo de participação. Ao invés de dizer que os humanos "transformam a natureza", os historiadores ambientais preferem

\footnotetext{
${ }^{4}$ Até hoje não encontrei um enunciado mais elegante desse princípio do que aquele de Johann Wolfgang von Goethe: "Dizer que o peixe existe para a água parece-me dizer menos do que [quando se diz] que o peixe existe na água e por meio da água; porquanto essa última afirmação expressa muito mais claramente o que é apenas sombriamente sugerido na primeira, a saber, que a existência das criaturas chamadas peixes é possível apenas se existir um elemento chamado água, e que esses peixes não somente existe, mas também se desenvolvem lá. A mesma coisa vale para todas as outras criaturas" (Goethe, 1952 apud Glacken, 1967, p. 536, ênfases no original).
} 
dizer, seguindo o enunciado de Tim Ingold (2002), que os humanos tomam parte, ao lado de outros seres, no processo em que a natureza transforma a si mesma.

Isto significa repensar as formulações atualmente dominantes nas ciências sociais - sobretudo no Brasil -, formulações que giram em torno da velha noção spinoziana de "segunda natureza". Tal posição teórica, comum entre os marxistas, sustenta que os humanos "fazem história" tão somente na medida em que artificializam o seu ambiente de vida, fabricando equipamentos técnicos fixos que domesticam a natureza "primeira" (silos, estradas, moinhos, etc.). ${ }^{5}$ Esse tipo de tese - muito propício a reivindicações de independência por parte de cientistas sociais desejosos de desatar qualquer ligação com as ciências naturais acaba caindo, facilmente, na armadilha reducionista de se subsumir processos da natureza sob o guarda-chuva de uma natureza controlada apenas socialmente, corroborando, assim, a ideia de uma natureza manejável, subordinada, externa e cujo metabolismo permanece fora da esfera social e discursiva (Swyngedouw, 2001).

Conforme argumentou Erik Swyngedouw (2001), mais interessante - embora reconhecidamente difícil de se aplicar na prática da pesquisa empírica - é seguir Henri Lefebvre e considerar que natureza, técnica, linguagem e representações são dimensões próprias com características particulares e irredutíveis, embora internalizem, constitucionalmente, as relações definidas pelas outras dimensões. Para abordar o conteúdo de qualquer uma delas é preciso expor o seu metabolismo com as demais, que são as relações internas responsáveis pela produção e pela significação. Desta forma, mantém-se a especificidade da abordagem dos cientistas sociais, que não tomam a natureza, como muitos de seus colegas no campo físico-natural, como um simples conjunto de coisas e relações objetivas que está "lá fora" e à qual a gente vai ao encontro, "descobre" e apresenta ao leitor.

\section{Mata Atlântica: do perspectivismo ameríndio ao hierarquismo europeu}

Há muitas evidências históricas e etnográficas indicando que as sociedades pré-modernas, sobretudo as sociedades tribais, eram e ainda são informadas por um profundo sentimento de pertença e comunalidade em relação aos não humanos. Em suas anotações sobre as formações econômicas anteriores ao capitalismo, Marx teorizou essa forma tribal de relacionamento com a biosfera. Vivendo na "unidade natural [espontânea] do trabalho com seus pressupostos materiais", os indivíduos consideram-se possuidores (ou fruidores) apenas na medida em que concebem a si mesmos como parte de uma comunidade (Marx, 1991) - uma comunidade mais do que humana, eu acrescentaria. Nessas sociedades, os humanos não enxergam em si mesmos nada muito diferente daquilo que os circunda e com o que interagem. Embora o meio em que vivem certamente lhes apresente ameaças, eles se sabem, por outro lado, ameaçadores de outras espécies. Considerando-se que, nessas sociedades tecnologicamente simples, a "produção dos meios imediatos de vida" inclui, de modo ainda bastante importante, a evitação da morte (fugir à predação por outras espécies animais), nada mais natural do que seus membros partilharem uma visão de mundo perspectivista, i.e., que expressa a ambivalência de ser uma espécie animal que caça e que é caçada. Assim, como condição "religiosa" de seu trabalho cotidiano, eles concebem a si mesmos como pertencendo a e participando de uma comunidade mais ampla, mais variada, mais poderosa e mais significativa do que aquela composta, simplesmente, por seus parentes humanos (consanguíneos e fictícios).

Como é que, no caminhar da história, esse inclusivismo é gradualmente substituído por uma percepção autossegregada e exclusivista? Em outras palavras, como é que "sociedades e indivíduos vêm a perceber, no conjunto dos elementos que compõem seu mundo, alguns deles como pertencendo à ordem da ação reflexiva e outros às forças da 'natureza bruta', às 'externalidades', aos 'arredores'?” (Sörlin \& Warde, 2007, p. 121-122). Embora Marx não tenha abordado essa questão - pelo menos não diretamente -, uma resposta marxiana teria de partir das mudanças no regime de propriedade para mostrar como o membro da comunidade se transforma, gradualmente, num mero trabalhador. Não me aventurarei aqui, evidentemente, a formular uma teoria

\footnotetext{
${ }^{5}$ Um dos primeiros sistematizadores dessa ideia foi o filósofo italiano Antonio Labriola (1908), que influenciou a obra do geógrafo Milton Santos.
} 
geral como essa. Gostaria, no entanto, de oferecer uma breve reflexão acerca de um caso histórico particular: o processo por meio do qual a conquista e a assimilação europeia das tribos e etnias indígenas da Mata Atlântica brasileira, a partir de 1500, engendraram uma sociedade mestiça antropocêntrica. Em outro lugar, eu argumento que a conquista e a assimilação (biológica e cultural) das populações ameríndias, pelos portugueses, foram acompanhadas por um processo de "alterização" da floresta (Cabral, no prelo).

Para os ameríndios, caçadores-coletores ou moradores de aldeias horticultoras sujeitas a deslocamentos periódicos, a floresta estava dentro da ordem social. Pesquisas antropológicas realizadas nos últimos vinte anos vêm mostrando que, para os povos indígenas sul-americanos, não existe aquilo que nós, ocidentais modernos, acostumamo-nos a chamar de "Natureza"; o que há é um mundo social todo-abrangente. Animais e plantas possuem subjetividade tal como os humanos: todos os seres são "pessoas" com pontos de vista particulares sobre eles próprios e sobre o cosmos que os contém e rodeia. Em oposição ao "naturalismo" ocidental - em que os humanos diferenciam-se de uma naturalidade biofísica universal a partir de seu pensamento ou espírito -, esse "animismo" ameríndio engendra uma humanidade ("espiritualidade") comum em que os seres se diferenciam entre si por seus atributos corporais.

Em outras palavras, não há uma alteridade "natural", mas sim diversas alteridades "culturais", diversas formas de encarar o mundo habilitadas pelas capacidades pertinentes a cada corpo. Assim, o modo como os humanos veem os não humanos e outras subjetividades que povoam o universo (os espíritos) é diverso do modo como esses seres veem os humanos e a si mesmos. Conforme nos explica Eduardo Viveiros de Castro:

Cada espécie de ser, a começar pela nossa própria espécie, vê-se a si mesma como humana. Assim, as onças se veem como gente: cada onça individual vê a si mesma e a seus semelhantes como seres humanos, organismos anatômica e funcionalmente idênticos aos nossos. Além disso, cada espécie ou tipo de ser vê certos elementos-chave de seu ambiente como se fossem objetos culturalmente elaborados ou definidos, como suportes de uma visada humana: o sangue dos animais que matam é visto pelas onças como cerveja de mandioca, o barreiro em que se espojam as antas é visto como uma grande casa cerimonial, os grilos que os espectros dos mortos comem são vistos por estes como peixes assados, etc. Em contrapartida, os animais não veem os humanos como humanos. As onças, assim, nos veem como animais de presa: porcos selvagens, por exemplo. É por isso que as onças nos atacam e devoram, pois todo ser humano que se preza aprecia a carne de porco selvagem. Quanto aos porcos selvagens (isto é, aqueles seres que vemos como porcos selvagens), estes também se veem como humanos, vendo, por exemplo, as frutas silvestres que comem como se fossem plantas cultivadas, enquanto veem a nós humanos como se fôssemos espíritos canibais - pois os matamos e comemos (Viveiros de Castro, 2007, p. 8-9).

“Animismo", "metempsicose", “zoantropia" são termos que poderiam ser usados para caracterizar esse traço cultural, mas então não estaríamos ultrapassando uma rasa interpretação etnocêntrica. Quando mergulhamos na profundidade significativa dos sistemas ameríndios, percebemos que esses traços denunciam, isto sim, uma concepção que reposiciona aqueles seres do mundo que nós, ocidentais modernos, acostumamo-nos a chamar de "naturais": para os ameríndios, eles não passavam de estados corpóreos particulares e transitórios da própria humanidade. Os nativos encaravam a floresta não como uma natureza exterior, mas como uma espécie de "sítio vital" em que todos os seres dialogavam culturalmente.

Para os ameríndios, provavelmente não faria muito sentido o conceito de matos que "nunca foram lavrados ou aproveitados", conforme aparece nas Ordenações Filipinas, de 1603. Os nativos praticavam sua horticultura de coivara dentro de um território amplo, mas bem definido; em outras palavras, tratava-se de um circuito territorial, e não - pelo menos não rotineiramente - de migração. Neste circuito, o tempo de pousio era muito dilatado, na ordem de dezenas de anos, possivelmente alcançando uma centena em algumas áreas de menor densidade populacional. Ainda assim, é provável que, durante os mais de mil anos decorridos entre o advento da agricultura, no planalto, e a chegada dos portugueses, cerca de metade da floresta semidecídua tenha sido derrubada e queimada pelo menos uma vez. $\mathrm{O}$ arroteamento se inseria dentro de uma temporalidade cíclica, uma espécie de "eterno retorno" que não previa a possibilidade 
de matas intocadas, mas apenas graus de regeneração e desenvolvimento vegetal.

$\mathrm{Na}$ visão de mundo adventícia, todavia, essa separação ontológica era fundamental. Os cristãos não enxergavam o domínio extra-humano como ser, mas como criação, produto divino destinado a ser matéria-prima. No começo dos tempos, Deus havia criado as "matas virgens" para que os humanos pudessem usufruir delas e, nessa marcha progressiva de apropriação e transformação, marcassem sua trajetória sobre a Terra. Gradativamente, esse ethos profético foi se impondo e se apropriando da paisagem florestal a partir de um esquema cultural fortemente estruturado em torno do contraste entre natureza e trabalho humano. Surgem então os "matos onde nunca entrou machado desde que Deus os criou", como na expressão do sargento-mor Diogo Moreno, em 1612 (Sluiter, 1949, p. 531).

Com a conquista dos povos indígenas pelos europeus e a decorrente mestiçagem biológica e cultural, o "separacionismo/hierarquismo" euro-lusitano acabou se mostrando mais poderoso do que o "perspectivismo" ameríndio. Na medida do possível, os neobrasileiros preservaram a riquíssima herança etnoecológica dos aborígenes: eles conseguiram reter o conhecimento das propriedades das plantas, do comportamento dos bichos, dos ciclos do tempo, das ameaças microscópicas. Comunidades neotradicionais como os caiçaras - resultados da mestiçagem lusitano-ameríndia, com pouca ou nenhuma influência africana - ainda hoje guardam em seu acervo cultural uma fração nada desprezível do estoque de conhecimento de seus "pais" indígenas. No litoral norte de São Paulo e sul do Rio de Janeiro, por exemplo, essas comunidades mobilizam entre 100 e 200 espécies de plantas em seu modo de vida (para fins alimentares, construtivo-artesanais, medicinais, etc.), a maioria delas nativa da Mata Atlântica (Begossi, 1998; Hanazaki et al., 2000).

Mas esse saber, desde o início da colonização e da miscigenação, foi sendo reproduzido dentro de uma nova estrutura mental - engendrada, ao nível da linguagem, por meio do alfabetismo e da gramaticalização ${ }^{6}$, dentro de uma outra atitude diante das coisas do mundo. A vocação dos mestiços, dos quais os bandeirantes paulistas são exemplo tão patente, "era de autoridades de mando e cutelo sobre bichos e matos e gentes, nas imensidades de terras de que iam se apropriando em nome de Deus e da Lei" (Ribeiro, 2006, p. 43). Os neobrasileiros conheciam muito do ambiente em que viviam, sim; mas não tanto para aproximar, conviver, conversar. Conheciam para rechaçar, dominar e conquistar.

Claro que este foi um processo lento e complexo, cheio de hesitações e continuidades. Os neobrasileiros rústicos, os mamelucos camponeses, sobretudo na era colonial, sempre estiveram "mais próximos do índio caçador que do agricultor moderno". Os curupiras, as mães e reis da mata, os anhangás, os mitos transformistas de criação de certos animais (como o macaco, na cultura caipira): tudo isso mostra que não se gestou, de uma hora para outra, um povo antropocêntrico e racionalista - como dizer que o somos, completamente, mesmo hoje em dia? E não esqueçamos que os portugueses, excitados pelo maravilhoso e prodigioso das novas terras, também não deixaram de contribuir com sua parcela de misticismo para o caldo cultural americano (Holanda, 1994).

Ainda assim, quando se coloca em perspectiva a formação da etnia neobrasileira, na longa duração, percebe-se que a tendência constante foi a de expulsar, gradativamente, a floresta do domínio das relações culturais. Exterioriza-se, virginiza-se a mata, transformando-a tanto em recurso quanto em ameaça, ambos situados numa outra esfera do mundo vivido - a esfera da "natureza", inexistente na ordem indígena. "As matas densas, que existem como testemunho da força criadora do novo continente na sua primitiva selvajaria, e ainda não profanadas pelo machado, chama-se no Brasil 'mato virgem "', relataram os naturalistas bávaros Johann Baptiste von Spix e Karl Friedrich von Martius (1938, v. 1, p. 151), no começo do oitocentos. A passagem gradual do "mato verdadeiro" ao "mato virgem" representou uma crescente "alterização" da floresta na formação da cultura mestiça, neobrasileira.

\footnotetext{
${ }^{6} \mathrm{O}$ impacto da alfabetização na transformação socioecológica da Mata Atlântica será tema de um trabalho futuro.
} 


\section{História ambiental como crítica cultural}

Seria essa, então, a "utilidade" da abordagem ambiental - um meio de ampliar o alcance das narrativas históricas? No âmbito disciplinar mais estrito, eu diria que sim, basicamente. No entanto, ainda que isso não seja pouco, acredito que os historiadores ambientais, por meio de suas pesquisas e reflexões, têm algo importante a oferecer não somente a seus colegas de profissão, mas à arena científica e cultural mais ampla.

A despeito das controvérsias técnicas e metodológicas em torno do resultado objetivo das suas investigações, os cientistas físico-naturais, em sua esmagadora maioria, concordam que as civilizações estão degradando os sistemas naturais que sustentam a vida humana. Seguidos relatórios de pesquisa mostram que nossos sistemas de suporte vital estão rapidamente declinando e que precisamos urgentemente reconhecer, representar e valorar, tanto econômica quanto "sentimentalmente", sua saúde e sua capacidade de continuar nos provendo serviços. Mas a ciência natural, por si mesma, parece incapaz de oferecer os instrumentos conceituais de que precisamos para operar essa mudança cultural. A tarefa básica dos estudiosos nas "eco-humanidades", dentre eles os historiadores ambientais, é oferecer uma crítica dos paradigmas culturais que vêm obliterando nossa visão acerca das atuações e responsabilidades desses negligenciados provedores de serviços. Um dos alvos mais importantes dessa crítica deve ser o esquema mental de atribuição de pertencimento, identidade e agência, nos relatos sobre a "criação" das paisagens terrestres (Plumwood, 2006).

Hoje em dia, quando mais de 90 por cento da Mata Atlântica "original" já foram convertidos em lavouras, pastos, cidades, estradas e wastelands, ela parece não ter mais nada de "natural". Os cientistas, principalmente aqueles ligados aos esforços conservacionistas, insistem na existência de um "bioma", mas a maioria de seus habitantes humanos ignora morar em um. Exceto talvez quando vai a um parque nacional, o cidadão médio da Mata Atlântica pensa morar na "cidade", não na "natureza". Enquanto para o cientista-ambientalista é difícil aceitar, por exemplo, a proposição de que a Mata Atlântica é melhor descrita como um "bioma humano"
- algo que supostamente diminuiria o apelo de muitos discursos conservacionistas -, parece difícil para o cidadão comum relativizar suas noções mais fundamentais de pertencimento.

Em última instância, contudo, ciência e senso comum enfrentam a mesma dificuldade: uma concepção muito estreita de "sociedade". Continuamos, na verdade, com o mesmo problema de representação dos nossos antepassados coloniais - a saber, a hiperseparação entre nós mesmos e a floresta. $\mathrm{O}$ bombardeamento de mensagens mais ou menos alarmistas a respeito da necessidade de preservar/conservar a natureza/ambiente parece ter um efeito apenas marginal sobre a massa da população brasileira. E isto não é por acaso. É claro que, como sugeri mais atrás, a racionalização antropocêntrica está ancorada, materialmente, na divisão do trabalho, e qualquer pedagogia ambiental que não inclua uma dimensão sensível - que não apele, de alguma maneira, aos sentidos e à prática cotidiana - estará fadada ao fracasso. Ainda assim, mesmo nos limites de seus moldes atuais, a educação pode fazer muito mais do que vem fazendo. Para pessoas educadas com uma historiografia e um ensino de história e geografia altamente antropocêntricos, admoestações preservacionistas "soltas" acabam soando pouco sinceras e/ou plausíveis. Ora, se a escola e as demais instituições pedagógicas (lato sensu) nos ensinam, desde o começo de nossas vidas, que o país foi construído exclusivamente pelos humanos que nos antecederam, como pode ser que agora, de uma hora para outra, dependamos de coisas e organismos não humanos para organizar nossa "sociedade"?

Em minha visão, os historiadores ambientais devem militar, essencialmente, para transformar o raciocínio histórico e a produção da memória cultural. Eles devem tentar mostrar que, em qualquer lugar e em qualquer tempo, as "sociedades" nunca são inteiramente humanas, como também nunca são inteiramente adultas ou inteiramente masculinas ou inteiramente racionais. "Sociedade", na verdade, é uma palavra que designa um processo de interação e não um conjunto específico de seres. Ao invés de presumirmos os componentes, que tal rastrearmos as relações? É delas que nasce qualquer sociedade. Para sobreviver e viver uma vida com significado, as pessoas e os povos humanos precisam conhecer, conviver e trabalhar com outros 
seres e processos sobre os quais eles não têm completo controle. Na Mata Atlântica de hoje, tanto os atributos "sociais", como malha político-administrativa, estrutura fundiária, distribuição populacional, etc., quanto os atributos "ambientais", como a composição, a estrutura e a funcionalidade das comunidades vegetais, evidenciam uma complexa história de convivência e mediação entre humanos e não humanos. Em outras palavras, a Mata Atlântica somos nós: é o nosso espaço compartilhado, nossa trajetória comum.

Estamos nos fazendo, todos juntos, ao longo do caminho. Como diria Riobaldo, personagem clássico de Guimarães Rosa, "a vida é mutirão de todos, por todos remexida e temperada" (Rosa, 2001, p. 477). Por isso, diríamos que, para o historiador ambiental, não se trata apenas de repovoar as paisagens históricas com a vida e o trabalho dos grupos humanos subalternos, como os ameríndios. Porque um projeto como este mantém a dicotomia entre atores/personagens e palco/cenário.

\section{Referências}

Abram, D. The spell of the sensuous: perception and language in a more-than-human world. New York: Vintage Books, 1997.

Anônimo. Diálogos das grandezas do Brasil. São Paulo: Melhoramentos, 1977.

Begossi, A. Resilience and neo-traditional populations. In: Berkes, F.; Folke, C. (Eds.). Linking social and ecological systems. Cambridge: Cambridge University Press, 1998. p. 129-157.

Bouwsma, W. J. The Renaissance discovery of human creativity. In: O’Malley, J. W.; Izbicki, T. M.; Christianson, G. (Eds.). Humanity and divinity in Renaissance and Reformation: Essays in honor of Charles Trinkaus. Leiden: E.J. Brill, 1993. p. 17-34.

Cabral, D. C. "O Brasil é um grande formigueiro": território, ecologia e a história ambiental da América portuguesa - Parte 1. Historia Ambiental Latinoamericana y Caribeña, 3(2), p. 467-489, 2014.

. Na presença da floresta: Mata Atlântica e história colonial. Rio de Janeiro: Garamond/FAPERJ, no prelo.

Catton, W. R., Jr. \& Dunlap, R. E. Environmental sociology: A new paradigm. The American Sociologist, 13, 41-49, 1978.

Clement, C. R. 1492 and the loss of Amazonian crop genetic resources - part I. Economic Botany, 53(2), 188-202, 1999.
Por outro lado, se animamos a paisagem ela mesma mostrando que, na verdade, não há qualquer palco para a História -, tudo, absolutamente tudo, imbui-se de ação e agência, e o mundo torna-se mais colorido, interessante e significativo. Para gerirmos melhor nossa relação com a "natureza", é imprescindível que descolonizemos isto é, que restituamos a essencialidade de - todos os subalternos, inclusive os não humanos (Cabral, 2014).

Olhando ao nosso redor, tanto em termos ecológicos e geológicos quanto em termos humanos e culturais, nós enxergamos, por toda parte, a mescla indissociável de múltiplas agências. Para qualquer porção da superfície terrestre que voltemos os olhos, formas de relevo pedem a nossa ajuda para contar histórias de movimentos tectônicos, vulcões, terremotos, deposições geológicas e intemperismo, entre muitos outros processos físicos. Mas isto é apenas o começo, já que a vida se infiltra por todos os lados, às vezes para o nosso dissabor - mas fazer o quê? É a vida.

Crosby, A. W., Jr. The past and present of environmental history. American Historical Review, 100(4), 1177-1189, 1995.

The Columbian exchange: biological and cultural consequences of $1492,30^{\text {th }}$ Anniversary Edition. Westport: Praeger Publishers, 2003.

Diamond, J. Armas, germes e aço: os destinos das sociedades humanas. 14. ed. Rio de Janeiro: Record, 2012.

Dovers, S. On the contribution of environmental history to current debate and policy. Environment and History, 6(2), 131-150, 2000.

Glacken, C. J. Traces on the Rhodian shore: nature and culture in Western thought from ancient times to the end of the eighteenth century. Berkeley: University of California Press, 1967.

Hanazaki, N.; Tamashiro, J. Y.; Leitão-Filho, H. F.; Begossi, A. Diversity of plant uses in two Caiçara communities from the Atlantic Forest coast, Brazil. Biodiversity and Conservation, 9(5), 597-615, 2000.

Holanda, S. B. Caminhos e fronteiras. 3. ed. São Paulo: Cia. das Letras, 1994.

Ingold, T. An anthropologist looks at biology. Man (New Series), 25(2), 208-229, 1990 
On the distinction between evolution and history. Social Evolution \& History, 1(1), 5-24, 2002.

Labriola, A. Essays on the materialistic conception of history. Chicago: Charles H. Kerr \& Co., 1908.

Laland, K. N.; Odling-Smee, J.; Myles, S. How culture shaped the human genome. Nature Reviews: Genetics, 11(2), 137148, 2010.

Marx, K. Formações econômicas pré-capitalistas. 6. ed. São Paulo: Paz \& Terra, 1991.

McNeill, J. R. The state of the field of environmental history. Annual Review of Environment and Resources, 35, 345-374, 2010.

McNeill, W. H. Plagues and peoples. New York: Doubleday, 1976.

Nash, R. Wilderness and the American mind. New Haven: Yale University Press, 1967.

. American environmental history: A new teaching frontier. Pacific Historical Review, 41(3), 362-372, 1972.

Pádua, J. A. As bases teóricas da história ambiental. Estudos Avançados, 24(68), 81-101, 2010.

Plumwood, V. The concept of a cultural landscape: Nature, culture, and agency in the land. Ethics and the Environment, 11(2), 115-150, 2006.

Reclus, E. A ação do homem como modificador das condições naturais, dominando e transformando a natureza. In: Andrade, M. C. (Org.). Elisée Reclus. São Paulo: Ática, 1985.

Ribeiro, D. O povo brasileiro: a formação e o sentido do Brasil. São Paulo: Cia. das Letras, 2006.

Rosa, J. G. Grande sertão: veredas. 19. ed. Rio de Janeiro: Nova Fronteira, 2001.

Russell, E. Evolutionary history: uniting history and biology to understand life on Earth. Cambridge: Cambridge University Press, 2011.

Rzepinska, M. The divine wisdom of Michelangelo in 'The Creation of Adam'. Artibus et Historiae, 15(29), 181-187, 1994.
Schama, S. Landscape and memory. Toronto: Vintage Canada, 1995.

Sewell, W. H., Jr. A theory of structure: Duality, agency, and transformation. American Journal of Sociology, 98(1), 1-29, 1992.

Sluiter, E. Report on the State of Brazil, 1612. Hispanic American Historical Review, 29(4), 518-562, 1949.

Sörlin, S.; Warde, P. The problem of the problem of environmental history. Environmental History, 12(1), 107-130, 2007.

Spix, J. B.; Martius, K. F. P. Viagem pelo Brasil. 3 v. Rio de Janeiro: Imprensa Nacional, 1938.

Stroud, E. Does nature always matter? Following dirt through history. History and Theory, 42(4), 75-81, 2003.

Swyngedouw, E. A cidade como um híbrido: natureza, sociedade e 'urbanização-cyborg'. In: Acselrad, H. (Org.). A duração das cidades: sustentabilidade e risco nas políticas urbanas. Rio de Janeiro: DP\&A, 2001. p. 83-104.

Viveiros de Castro, E. A natureza em pessoa. Encontro Visões do Rio Babel - Conversas sobre o futuro da bacia do Rio Negro. Manaus: Instituto Socioambiental e Fundação Vitória Amazônica, 2007.

Wells, H. G. Uma breve história do mundo. Porto Alegre: L\&PM, 2011.

Wendel, J. F.; Cronn, R. C. Polyploidy and the evolutionary history of cotton. Advances in Agronomy, 78, 139-186, 2003.

White, L., Jr. The historical roots of our ecologic crisis. Science, 10, 1203-1207, March 1967.

White, R. American environmental history: The development of a new historical field. Pacific Historical Review, 54(3), 297-335, 1985.

. From wilderness to hybrid landscapes: The cultural turn in environmental history. The Historian, 66(3), 557-564, 2004.

Worster, D. Appendix: Doing environmental history. In: Worster, D. (Ed.). The ends of the Earth: Perspectives on modern environmental history. Cambridge: Cambridge University Press, 1988. p. 289-307. 